\title{
Hogyan előzzük meg a gyermekbántalmazást? A prevenciós munka jelentősége és kihívásai
}

\author{
How to prevent child abuse? Importance and challenges of prevention
}

\author{
Szerzők: Tománé Mészáros Andrea ${ }^{a} \bigotimes$, Kovács Zsuzsanna ${ }^{b}$, Domján Gyulac, Gadó Klárac \\ Soósné Kiss Zsuzsanna ${ }^{c}$ \\ a: Országos Közegészségügyi Intézet, Budapest, Semmelweis Egyetem Doktori Iskola; b: Házi \\ Gyermekorvos egyéni vállalkozó, Budapest; c: Semmelweis Egyetem, Egészségtudományi Kar, \\ Egészségfejlesztési és Klinikai Módszertani Intézet, Egészségtudományi Klinikai Tanszék, Budapest
}

Beküldve: 2018. 06. 11.

doi: $10.24365 /$ ef.v59i5.323

Összefoglaló: A gyermekbántalmazást a WHO népegészségügyi problémának minősítette. A cikk a fogalmi meghatározások és a rövid történeti áttekintés mellett a hangsúlyt a prevenciós lehetőségek bemutatására és annak nehézségeire helyezi. Ismerteti a magyar törvényi kereteket, a hatályos módszertani irányelveket. Rávilágít a jelzőrendszeri tagok szerepére, feladataira, különösképpen a jelzési kötelezettségre, annak törvényi felelősségére.

Kulcsszavak: gyermekbántalmazás; abúzus; elhanyagolás; jelzőrendszer; megelőzés

Summary: Child abuse has been classified as a public health issue by WHO. Besides defining concepts and a brief historical overview, the article puts emphasis on the possible ways of prevention and its difficulties. It describes the Hungarian legal framework and the existing methodological guidelines. The article also highlights the role and tasks of people in the warning system, especially the obligation of warning and its statutorily ability.

Keywords: child maltreatment; child abuse; neglecting; warning system; prevention

OGYEI: Országos Gyermek-egészségügyi Intézet

KSH: Központi Statisztikai Hivatal

WHO: World Health Organization

\section{BEVEZETÉS}

A gyermekbántalmazás és elhanyagolás általános jelenség és egyre aggasztóbb probléma. A felnőtt áldozatok mindennapjait befolyásolják a gyermekkori viselkedésminták. A gyermekkorban elszenvedett nélkülözés és/vagy rossz bánásmód egész életre kiható traumákat okoz. A társadalom elemi érdeke, hogy a megelőzést, a felismerést és a kezelést támogassa.
A megelőzés, valamint a hatékony kezelés többféle tényező együttesének függvénye. Szükség van a társadalom fokozott figyelmére, arra, hogy a szakemberek, a közvélemény, a véleményformálók, az átlagemberek tudatosítsák, kinyilvánítsák a társadalmi gondolkodás szintjén az erőszak elfogadhatatlanságát. Szükség van a segítő szakemberek megfelelő tudásszintjére és a tudás folyamatos frissítésére, bővítésére. Ehhez szükségesek a szisztematikus módszertannal kifejlesztett és konzekvensen alkalmazott szakmai irányelvek, melyek igazoltan javítják az ellátás minőségét. ${ }^{1}$ Nem utolsó sorban, kellenek hatékony megelőzési eszközök, továbbá a feladathoz rendelt pénzeszközök. 


\section{HÁTTÉR, ELŐZMÉNYEK}

A WHO definíciója szerint: „A gyermek bántalmazása és elhanyagolása (rossz bánásmód) magában foglalja a fizikai és/vagy érzelmi rossz bánásmód, a szexuális visszaélés, az elhanyagolás vagy hanyag bánásmód, a kereskedelmi vagy egyéb kizsákmányolás minden formáját, amely a gyermek egészségének, túlélésének, fejlődésének vagy méltóságának tényleges vagy potenciális sérelmét eredményezi egy olyan kapcsolat keretében, amely a felelősségen, bizalmon vagy hatalmon alapul." ${ }^{2}$ Sok tényező függvénye, hogy a bántalmazás milyen méretű károsodásokat okoz. Függ a bántalmazás súlyosságától, attól, hogy mennyire volt rendszeres, nagyon fontos, hogy milyen életkorban érte a gyermeket és kiemelkedő, hogy kapott-e a környezettől segítséget. ${ }^{3}$

\section{TÖRTÉNET, EPIDEMIOLÓGIA}

A XIX. századig a gyermekbántalmazás ismeretlen fogalom volt, mert annyira a hétköznapi élet része volt. Pukánszky Béla kiváló könyvben dolgozta fel a gyermekkor történetét. ${ }^{4}$ Ezek az értekezések sokszor azonban a szakembereket is megosztják, melynek oka egyrészt abban keresendő, hogy kevés hiteles forrással rendelkezünk, másrészt változott az idők folyamán az is, hogy mit tekintünk bántalmazásnak. 1899-ben jelent meg az első, a gyermekek védelméről szóló charta Angliában, majd ezt beemelték az egyes angolszász országok jogrendjébe (pl. Dél-Ausztrália). ${ }^{5}$ A Gyermekjogi Charta először adott lehetőséget a hatóságoknak, hogy törvényi úton beavatkozhassanak a szülő-gyermek kapcsolatba, ha a gyermekeket rossz bánásmód, bántalmazás éri. A törvény iránymutatást adott a gyermekmunka végzésére és a koldulást is szabályozta. A Charta érdekessége, hogy ezt 1822ben megelőzte az állatok kínzását megtiltó törvény, a Martin's Act. ${ }^{6}$

Magyar vonatkozásban a Kiegyezés után törvények egész sora foglalkozott a gyermekek védelmével. Az 1872. évi VII. tc. az ipartörvény 43. §-a megtiltotta a tanoncok cselédként való dolgoztatását és bántalmazását, majd az új 1884. évi XVII. ipartörvény szabályozta az iskolába járást, a betegápolási jogosultságot. Az 1878. évi V. tc. az ún. „Csemegikódex" - a büntető törvénykönyv - 83. §-a kizárta a
12 éven aluli gyermekek büntethetőségét, súlyosan büntette a magzatelhajtást, az újszülött megölését és a gyermek kitételét. A Széll Kálmán (1843-1915) miniszterelnöksége alatt hozott 1901. évi VIII. és XXI. tc. megnyugtatóan rendezte a gyermekek intézményi ellátását. Nemcsak törvényi szinten történt meg a szabályozás, hanem megfelelő pénzügyi finanszírozás is társult hozzá az államilag beszedett pótadókból. Tulajdonképpen ettől az időtől számoljuk a hazai gyermekvédelem kezdetét. ${ }^{7}$

A gyermekbántalmazás tudományos vizsgálatát John Caffey amerikai radiológus kutatásai indították el. Ő 1946-ban írta le azokat a sérüléseket, amelyek nem véletlen baleset, hanem szándékosság következtében jöttek létre. Az önálló kórkép elnevezése Henry Kempe gyermekgyógyász professzor nevéhez füződik. Ő használta először 1962-ben a „battered child syndrome" vagyis a megvert (bántalmazott) gyermek szindróma kifejezést. ${ }^{8}$ A magyar szakirodalomban az első közlemény Antoni Pál nevéhez fűződik, aki 1968-ban, az Orvosi Hetilapban publikált a témáról. ${ }^{9}$

A bántalmazás megítélésében nagyon nagy a különbség a kultúrák és az országok között. $\mathrm{Az}$ adatok ellentmondásosak, aminek több oka is van. Egyrészt visszavezethető a bántalmazás definíciós problémájára, másrészt a kutatási módszerek eltéréseire.

A nemzetközi és a hazai kutatások is alátámasztják, hogy a gyermekeket bántalmazó személyek csaknem $80 \%$-ban a vér szerinti szülők. Majdnem egyforma mértékben kap testi fenyítést a gyermek az apától és az anyától. Egyes tanulmányok felvetik, hogy mivel az anya több időt tölt a gyermekkel, esetenként tőle kap több verést. ${ }^{10}$

A statisztikai adatok szerint minden negyedik lány és minden hetedik fiúgyermek esik áldozatul szexuális bántalmazásnak a 18. életéve betöltése előtt. ${ }^{11}$

Kutatók szerint a látencia becsült adata a nyugateurópai országokban 1:10, míg Magyarországon 1:25 arányú. A KSH adatai szerint a gyermekpopuláció 10\%-a tekinthető veszélyeztetettnek. $\mathrm{Az}$ adatgyűjtés pontatlansága és a meghatározások sokfélesége miatt ezeket alábecsültnek tartják. ${ }^{1}$

\section{A BÁNTALMAZÓ SZÜLŐK JELLEMZŐI}

$\mathrm{Az}$ ártalmas gyermekkor komoly, életre szóló kihatással van az egyénekre. Gyakran tapasztaljuk, 
hogy a bántalmazott gyermek felnőve maga is bántalmazó szülő lesz, vagy bántalmazó kapcsolatokba kerülve ismételten áldozattá válik. Azoknál a szülőknél, akik fizikailag és/vagy érzelmileg bántalmazzák a gyerekeiket, számos jellemző viselkedéssel találkozunk.

Vannak olyan szülők, akik a saját gyermekkorukat idealizálják, olyan képet rajzolnak, amely soha nem volt. Mélyen eltemetik magukban a valóban átélteket, mert szégyellik bevallani, hogy bántották őket. Mások azonban képesek erről beszélni és megosztani a szörnyü, nyomasztó élményeiket. Gyakran találkozunk olyan szülői módszerrel, amely a gyermekkel szemben irreális, nem a korának megfelelő elvárásokat támaszt. Amennyiben a gyermek nem képes megfelelni az elvárásoknak, akkor fizikai és érzelmi terrort alkalmaznak vele szemben. A legtöbb ilyen szülő a gyermekét értéktelennek, butának, rossznak tartja. Esetenként előfordul, hogy a gyermek viselkedése vált ki agressziót a szülőből (pl. a sírás a megrázott gyermek szindróma esetén). A szülők miután saját szocializációjuk kapcsán nem élhették meg a pozitív szülői eszközöket, nincs mintájuk arra, hogyan is kellene a saját gyermekükkel jól, értően viselkedni. Sokszor ezek a szülők elszigetelődnek, így nehézséget okoz a segítésük is. Mindenképpen szót kell ejteni egy speciális, ritkán előforduló kórképről, a "Münchausen by proxi” szindrómáról. Általában labilis lelki állapotú, gyakran pszichiátriai betegségekkel terhelt anya az elkövető, és az áldozat a saját gyermeke. Ezek a gyermekek sokat betegek, bizarr, gyakran összefüggést nem mutató tüneteket produkálnak. Megalapozott diagnózist nehéz felállítani náluk. új betegség tünetek keletkeznek, vagy a már meglévő tünetek súlyosbodnak, amikor az anya a közelben van. Sokszor kerülnek kórházba ezek a gyermekek, szinte ki-be járnak a különböző egészségügyi ellátó rendszerekbe. A külvilág számára az anya a beteges gyermekét gondosan ápoló szülő képét festi le. A közösségi médiák megjelenése is tág teret ad az „aggódó anya” imázs fenntartására. A „gondos anya” képe alatt azonban az anya a betegségek előidézésével a környezete, olykor az egészségügyi személyzettől akar figyelmet, elismerést kicsikarni. Nehezen felismerhető és többségében rossz prognózisú kórkép, ami gyakran a gyermek halálával ér véget. Erős szakmai vita van arról, hogy pszichiátriai betegségről vagy gyermek- bántalmazásról van-e szó. Vannak olyan vélemények is, hogy ez inkább büntetőjogi, gyámügyi kategória, mint egészségügyi. Magyarországon az agárdi és a gyöngyösi csecsemőhalálozások hátterében az ombudsmani vizsgálat megállapításai szerint ez a kórkép állt fenn. ${ }^{12,13}$

\section{JOGSZABÁLYI KÖRNYEZET, JELZŐRENDSZER}

Magyarország 1991-ben csatlakozott a gyermekek jogairól szóló ENSZ egyezményhez (1991. évi LXIV. törvény). 1997-ben megszületett a Gyermekvédelmi törvény (1997. évi XXXI. tv a gyermekek védelméről és a gyámügyi igazgatásról), amelynek eredményeként gyermekjóléti szolgálatokat hoztak létre, és kialakították a gyermekvédelmi jelzőrendszert, a bántalmazott és veszélyeztetett gyermekek kiszűrésére és segítésére. ${ }^{14}$ A Gyermekvédelmi törvény rögzítette azoknak a (nem gyermekvédelmi feladatot ellátó) szerveknek a feladatait is, amelyeknek jelzési és együttmúködési kötelezettségük van a gyermekjóléti szolgálatok felé. A törvény 2002-es módosítása kimondja „A gyermek nem vethető alá kegyetlen, embertelen, megalázó testi fenyítésnek, büntetésnek vagy bánásmódnak.". ${ }^{15}$

2004-ben alkották meg az Országos Gyermekegészségügyi Intézet (OGYEI) módszertani irányelvét, amelyet 12 év elteltével, 2016-ban követett egy új, korszerú a nemzetközi keretrendszerhez igazított módszertani irányelv „Egészségügyi szakmai irányelv - Az egészségügyi ellátók feladatairól gyermekek bántalmazásának, elhanyagolásának gyanúja esetén" címmel. 2011-ben szintén az OGYEI indította el a www.gyermekbantalmazas.hu weboldalt és annak Facebook felületét. Ez az egyetlen, széles spektrumot átfogó magyar nyelvű weboldal ebben a témában. A „Szakembereknek” aloldalon a fenntartók tematikusan összegyűjtötték a jelzőrendszeri tagok részére kiadott módszertani ajánlásokat, melyek áttekintése segítséget adhat a szakmák közötti kompetenciahatárok tisztázására. 2016-ban több törvényt is módosítottak. Ezek:

- a gyermekek védelméről és a gyámügyi igazgatásról szóló 1997. évi XXXI. törvény,

- az egészségügyről szóló 1997. évi CLIV. törvény, valamint

- az egészségügyi alapellátásról szóló 2015. évi CXXIII. törvény. 
2016. január 1-jével lépett hatályba (a szakaszos hatálybalépés második részeként) a 2015. évi CXXXIII. törvény az egyes szociális és gyermekvédelmi tárgyú törvények módosításáról. A módosítás értelmében 2016. január 1-jétől a családsegítés csak gyermekjóléti szolgáltatással integráltan egy szervezeti és szakmai egységben - múködhet: települési szinten a család- és gyermekjóléti szolgálat, járási szinten a család- és gyermekjóléti központ keretében. Mindkét szolgáltatás továbbra is önkormányzati feladat marad. ${ }^{16}$

A gyermekbántalmazás és elhanyagolás komplex probléma, ezért ennek kezelése, megelőzése csak komplex együttmúködéssel lehetséges, melyben a jelzőrendszer tagjainak együttműködési, kölcsönös tájékoztatási kötelességük van. Ez törvényben rögzített feladat, kötelezettség, melynek elmulasztása a törvény által szankcionált. Veszélyeztetés esetén a helyzetet felismerőnek kötelessége jelzéssel élni a gyermekjóléti szolgálat felé, és szükség esetén kötelessége hatósági eljárást kezdeményezni. Mindezek elmulasztása foglalkozás körében elkövetett gondatlanságnak minősül, amely fegyelmi felelősségre vonást eredményezhet. ${ }^{17}$

\section{A GYERMEKBÁNTALMAZÁS MEGELŐZÉSE}

Az áldozathibáztatásnak jelentős kultúrája van mind hazánkban, mind külföldön. Az abúzusprevenció három lépcsőre épít, a primer, a szekunder és a tercier prevencióra. Mindhárom lépcső fontos eleme, hogy ne az áldozattá válást előzzük meg, hanem az elkövetővé válást.

A primer prevenció szerteágazó társadalmi feladat. A primer prevenció körébe tartoznak olyan területek, mint a jogi terület (hogyan, milyen módon szankcionálja az állam a bántalmazás elkövetését), a gazdasági (milyen jövedelemhez, munkához juthatnak a családok), a szociálpolitikai terület (milyen családtámogatási rendszerek vannak az adott országban). A primer prevenció elsősorban tájékoztató jellegú információk átadása. Ehhez nem is kell feltétlenül szakembernek lenni. Ideális esetben akár a szülő is elkezdheti ezt alsó korhatár nélkül. Erre kiváló példa a „fehérnemúszabály”, a jó és rossz érintés közötti különbség tudatosítása. A fehérneműszabályt az Európa Tanács dolgozta ki szülők és gondviselők számára azért, hogy minél egyszerűbben tudjanak beszélgetni gyermekükkel a szexuális bántalmazás megelőzéséről. A prevenciós program alapja a jó otthoni kommunikáció, a nyitott, de határozott párbeszéd. Fontos a félelemmentes környezet megteremtése és a gyermek korának megfelelő nyelvezet használata. A nyílt kommunikációt a gyermekek többsége nagyon jól kezeli, ezért a bátortalanabb szülőket biztatni kell ennek alkalmazására. A program tartalmaz egy rövid animációs kisfilmet, amelyhez egy mesekönyv csatlakozik „Kiko and the Hand” címmel. A programnak öt fö üzenete van: 1. A tested csak a tiéd. 2. Jó érintés, rossz érintés. 3. Jó titok, rossz titok. 4. A felnőtt felelőssége a megelőzés és a védelem. 5 . További gondolatok a fehérnemüszabályhoz. Egyszerü üzenetek, amelyeket már 2-3 éves korban is értenek a gyermekek. ${ }^{18}$

Kora gyermekkorban törekedni kell a bizalmas légkör kialakítására. Sokat segít, ha a gyermekeknek vannak szavaik, kifejezéseik az intim testrészeik megnevezésére. A primer prevenció területén hangsúlyos szerepe van a jól képzett védőnőnek. Segítheti a szülőt a korszerű ismeretek átadásában, az értő kommunikációban, az agressziómentes nevelési stratégiák kialakításában, a pozitív szülői minták erősítésében.

A szekunder prevenció a rizikócsoportokra irányuló megelőző tevékenység. Itt különösen fontos a védőnő, valamint a gyermekjóléti szolgálatok munkatársainak szerepe. A védőnő folyamatában látja a családok életét, így módja van korán észlelni a családi diszfunkciót. Feladatai közé tartozik a bántalmazás rizikófaktorainak felismerése, kiszúrése. A szekunder prevenció a gyermekbántalmazásban már érintett családokra irányul, az ő célzott megsegítésük a feladat. Kiemelten fontos a gyermek védelme a további bántalmazástól. Folyamatos támogatás mellett törekedni kell a szülői képességek fejlesztésére. Mind az egészségügyi, mind a szociális szférában dolgozó szakemberek részéről fontos, hogy jól felkészültek legyenek az ilyen családokkal való munkára, így a rendszeres képzésük elengedhetetlen. ${ }^{19,20}$

Az utóbbi időben számos olyan eset került napvilágra, melyben a gyermekek hosszú szenvedésnek voltak kitéve, és olykor a rossz bánásmód a halálukat okozta. Volt olyan eset, amiről a jelzőrendszer tagjai, közöttük a védőnők és házi gyermekorvosok késve, nem szakszerúen, vagy egyáltalán nem jeleztek. Volt olyan eset is, amelyben a jelzőrendszer tagjai tudtak az esetről, „mindenki csinált 
valamit", de nem intézkedtek hatékonyan a szakmai előírásoknak megfelelően, és ez tragikus végkifejlethez vezetett. Ezek az esetek életre hívták a „2016. évi CLXV. törvény egyes gyermekvédelmi és egészségügyi tárgyú törvényeknek a gyermekek biztonságának és védelmének fokozása érdekében történő módosításáról" szóló törvényt, melynek alapján a védőnői és házi gyermekorvosi ellátás nem utasítható vissza. ${ }^{21}$

A tercier prevenció magának az áldozatnak a kezelését jelenti, és arra irányul, hogy a bántalmazás megismétlődését elkerülje. A bűncselekmények áldozatainak segítéséről és az állami kárenyhítésről szóló 2005. évi CXXXV. törvény értelmében az áldozatsegítő szolgálatok a bűncselekmények és tulajdon elleni szabálysértések áldozatai számára tudnak segítséget nyújtani. A területi igazságügyi szolgálatok a járási/kerületi hivatalokban múködnek. Sérelemnek tekintendő a testi vagy lelki sérülés (súlyos félelem, szorongás) és az érzelmi megrázkódtatás (trauma, pszichés zavar) és olyan vagyoni kár, amely a cselekménnyel ok-okozati összefüggésben áll. ${ }^{22} \mathrm{~A}$ tercier prevenció nemcsak az áldozatra fókuszál, hanem a hozzátartozók segítésére is. Fontos a folyamatos utánkövetés. Segíteni kell a gyermek felépülését a traumából, támogatni kell a további fejlődését. Nagyon fontos, hogy a gyermeknek új esélyt kell adni. Szakszerü segítséggel átkeretezhetőek a gyermekkori rossz tapasztalatok. ${ }^{23}$

\section{A SEGÍTSÉGNYÚJTÁS LEHETŐSÉGEI}

Ha fény derül a bántalmazás tényére, akkor az első és legfontosabb feladat a további bántalmazás megelőzése, megakadályozása. Ez elsősorban a gyermekvédelmi rendszer feladata, ami rendkívüli körültekintést igényel. Fontos egyrészt a gyermek támogatása, másrészt a család segítése. Ehhez elengedhetetlen a bizalmi légkör kialakítása. Ha a bántalmazó szülő, vagy annak párja, kér segítséget, akkor nagyobb az esélye a bántalmazás abbahagyásának. Azonban a bántalmazó szülők nehezen tudnak segítséget kérni és elfogadni. Ilyenkor a gyermek védelme érdekében szükséges a jelzőrendszer bármely tagja részéről a jelzés megtétele az intézkedésre jogosult szervezet felé. A család gondozásba vétele, az egyéni családgondozási terv kialakítása és konzekvens kísérése fontos támasz a gyermeknek. A bántalmazás abbahagyása hosszú folyamat, melynek során a szülőnek rendszeres megerősítésre, van szüksége. Támogatni kell abban, hogy egy kiélezett helyzetben van más alternatíva is a bántalmazás helyett. Csak szisztematikus munkával állítható helyre a gyermek bizalma a szülő iránt.

\section{ÖSSZEGZÉS}

A gyermekbántalmazás megelőzésében nagy szerepe van annak, ha társadalmi szinten elutasítjuk a bántalmazás minden formáját. Az ártalmas gyermekkor egész életre kiható testi, lelki, egészségi és személyiség fejlődési zavart okoz. Súlyos bántalmazás esetén kimutathatóak a transzgenerációs hatások is. A bántalmazott gyermekből bántalmazó szülők válhatnak. Ilyen módon a hibás szociális minták generációról generációra átadódnak. ${ }^{8}$ A prevenciós munka célja ennek a káros folyamatnak a megszakítása. Ebben az egészségügyi alapellátásban dolgozó védőnőnek, valamint a szociális és gyermekjóléti rendszer dolgozóinak kulcsszerepe van. Kiemelt feladat a bántalmazás veszélyeire felhívni a figyelmet, fokozottan kell kontrollálni a rizikócsoportokat. Támogatni kell a szülőket a pozitív szülői attitűdök megismerésében és alkalmazásában. Amennyiben minden segítség ellenére a szülók nem képesek a gyermekeket ellátni, úgy a szakemberek felelőssége a jelzés, az intézkedési jogkörrel felruházott szervezetek felé. A cél a gyermek érdeke szerinti legjobb megoldás megtalálása és a cselekvés. A magyarországi törvények és módszertani irányelvek jók, hozzáférhetőek, érvényre juttatásuk a gyermekkel foglalkozó szakemberek közös felelőssége. 


\section{HIVATKOZÁSOK}

\footnotetext{
${ }^{1}$ Kovács Zs, Keller É, Sonnevend M, et al. (eds.). Professional healthcare guidelines-About the tasks of healthcare providers in case of suspicion of child abuse or neglect of children [Egészségügyi szakmai irányelv - Az egészségügyi ellátók feladatairól gyermekek bántalmazásának, elhanyagolásának gyanúja esetén] http://www.ijsz.hu/UserFiles/001148 eszi honlapra 20160608 2.pdf Elérve: 2018. 05. 15.

${ }^{2}$ Krug EG, Dahlberg LL, Mercy JA, et al. (eds.). World report on violence and health [Világjelentés az erőszakról és az egészségről WHO], Geneva, 2002. http://www.who.int/violence injury prevention/violence/world report/en/summary en.pdf Elérve: 2018. 05. 15.

${ }^{3}$ Urban Él. The influence of the environment on the development of anxiety and how it stays permanent [A környezet befolyásoló hatása a szorongás kialakulásában, állandósulásában] Új Pedagógiai Szemle. 2007;57;1:70-89. [Hungarian] http://epa.oszk.hu/00000/00035/00110/ Elérve: 2018. 05. 17.

${ }^{4}$ Pukánszky B, Vajda Zs. The story of childhood (excerpts) [A gyermekkor története (részletek)] http://www.pukanszky.hu/Gyermekkor 2001/2 \%C3\%93kor.pdf Elérve: 2018. 05. 17.

${ }^{5}$ An Act relating to the Protection of Children [Assented to, December 21st, 1899.]

https://www.findandconnect.gov.au/ref/sa/objects/pdfs/Children's\%20Protection\%20Act\%201899.pdf

Elérve: 2018. 10. 06.

${ }^{6}$ Martin's Act United Kingdom In animal rights: Animals and the law [1822]

https://www.britannica.com/topic/Martins-Act Elérve: 2018. 10. 14.

7 Baska G, Hegedús J. Égi iskolák, földi múhelyek. Tanulmányok a 65 éves Németh András tiszteletére. DOI:

10.184599/nasz.20159.23 http://mek.oszk.hu/14600/14688/pdf/14688.pdf Elérve: 2018. 10. 06.

${ }^{8}$ Kempe CH, Silverman FN, Steele BF, et al. The Battered Child Syndrome. Journal of the American Medical Association. 1962;181:17-24.

${ }^{9}$ Antoni P. A megkínzott gyermek syndroma. Orv Hetil. 1965;106:1934-1937.

${ }^{10}$ Innocenti Social Monitor 2003 https://www.unicef-irc.org/publications/series/21/ Elérve: 2018. 05. 17.

${ }^{11}$ Révész Gy. Parental treatment - child abuse [Szülői bánásmód-gyermekbántalmazás] Új

Mandátum Könyvkiadó, Budapest, 2004. [Hungarian]

${ }^{12}$ Győrffy Zs. The Commissioner for Fundamental Rights reports in AJB-3039/2013. number of cases [Az alapvető jogok biztosának jelentése az AJB-3039/2013. számú ügyben] http://www.ajbh.hu/documents/10180/111959/201303039.pdf/52dd3596-954f-422a-99b6-3539c66c38ad?version=1.0\&inheritRedirect=true Elérve: 2018. 10. 06.

${ }^{13}$ Győrffy Zs. The Commissioner for Fundamental Rights reports in AJB-4239/2016 number of cases [Az alapvető jogok biztosának jelentése az AJB-4239/2016. számú ügyben] http://www.ajbh.hu/documents/10180/2500969/Jelent\%C3\%A9s+az+\%C3\%A9henhalt+gy\%C3\%B6ngy\%C3\%B6si+kisgyer-

mek+\%C3\%BCgy\%C3\%A9ben+4239 2016/4c7f036b-05c6-436d-b7e1-a9e0bec2be38?version=1.0\&inheritRedirect=true Elérve: 2018. 10. 06.

${ }^{14}$ Act XXXI of 1997 on the Protection of Children and Guardianship [1997. évi XXXI. törvény a gyermekek védelméről és a gyámügyi igazgatásról] https://net.jogtar.hu/jr/gen/hjegy doc.cgi?docid=99700031.TV Elérve: 2018. 05. 19.

${ }^{15}$ Act IX of 2012 on the amendments of Act XXXI of 1997 on the Protection of Children and Guardianship [2002. évi IX. törvény a gyermekek védelméról és a gyámügyi igazgatásról szóló 1997. évi XXXI. törvény módosításáról]. https://mkogy.jogtar.hu/?page=show\&docid=a0200009.TV Elérve: 2018. 05. 19.

${ }^{16}$ EMMI Department of Social Services and Child Welfare - Integration of Family Assistance and Child Welfare Services and the formation of Child Welfare Centers [EMMI Szociális és Gyermekjóléti Szolgáltatások Főosztálya - A családsegítés és a gyermekjóléti szolgáltatás integrálása, család- és gyermekjóléti szolgálatok, valamint család és gyermekjóléti központok kialakítása].

${ }^{17}$ Act XXXI of 1997 on the Protection of Children and Guardianship [1997. évi XXXI. törvény a gyermekek védelmérôl és a gyámügyi igazgatásról]. https://net.jogtar.hu/jr/gen/hjegy doc.cgi?docid=99700031.TV Elérve: 2018. 05. 19.
} 
${ }^{18}$ Council of EuropeTeach your child The Underwear Rule http://underwearrule.org/source/text_en.pdf Elérve: 2018. 05. 21.

${ }^{19}$ Ágoston I, Betlehem J, Deutsch K, et al. Legal regulation of health education [Az egészségügyi képzések jogi szabályozása](2015) https://www.tankonyvtar.hu/hu/tartalom/tamop412b2/2013-0002 az egeszsegugyi kepzesek jogi szabaIyozasa/EJ/sejjs523g.htm Elérve: 2018. 10. 14.

${ }^{20} \mathrm{~g} / 2000$. (VIII. 4.) Regulation on the training of personal care providers and social examinations [SzCsM rendelet A személyes gondoskodást végző személyek továbbképzéséről és a szociális szakvizsgáról] https://net.jogtar.hu/jogszabaly?docid=a0000009.scm Elérve: 2018. 10. 14.

${ }^{21}$ Act CLXV of 2016 on Amend Certain Child Protection and Health Issues to Enhance the Safety and Security of Children [2016. évi CLXV. törvényegyes gyermekvédelmi és egészségügyi tárgyú törvényeknek a gyermekek biztonságának és védelmének fokozása érdekében történő módosításáról] https://net.jogtar.hu/jogszabaly?docid=A1600165.TV\&timeshift=ffffff4\&txtreferer=00000001.TXT Elérve: 2018. 10. 06.

${ }^{22}$ Act CXXXV. of 2005 on Assistance to Victims of Crime and State Compensation [2005. évi CXXXV. törvény a búncselekmények áldozatainak segítéséről és az állami kárenyhítésről] https://net.jogtar.hu/jogszabaly?docid=a0500135.tv Elérve: 2018. 10. 06.

${ }^{23}$ Katonáné PE. Methodological Manual The Role and Responsibility of the Child Protection Service in Preventing and Treating Child Abuse and Neglect [Módszertani füzet A gyermekvédelmi feladatot ellátó szervek szerepe és felelőssége a gyermekbántalmazás és elhanyagolás megelőzésére és kezelésére] http://www.3sz.hu/sites/default/files/Modszertani fuzet 2004.pdf Elérve: 2018. 10. 14. 